\title{
Türki Cumhuriyetlerde Telafi ve Etkinlik Hipotezi Geçerliliğinin Sinanmasi
}

\author{
Seda BAYRAKDAR ${ }^{1}$ ve Semanur SOYYİĞİT ${ }^{2}$
}

$\ddot{O} z$

Liberalleşme eğilimlerinin bir yansıması olan küresel sisteme entegrasyon çabalarının göstergelerinden biri ticari açıklığın derecesidir. 1991 yılından sonra bağımsızlığa kavuşan Türki Cumhuriyetlerde (Azerbaycan, Kırgızistan, Kazakistan, Türkmenistan, Tacikistan ve Özbekistan) ortaya çıkan ekonomi-politik yap1 değişimlerinin ve artan küreselleşme çabalarının kamu harcamaları kanalı üzerinden kamu büyüklüğüne etkisi iktisat teorisinde etkinlik ve telafi hipotezi ile incelenmektedir. Çalışmanın odak noktası, bu ülkelerde söz konusu hipotezlerin geçerliliklerinin sınanmasıdır. Küreselleşmenin göstergelerinden biri olarak ticari açıklık ve kamu büyüklüğünün göstergesi olarak da kamu harcaması verileri kullanılmıştır. Analiz 1997-2017 dönemini kapsamaktadır. Ampirik sonuçlar Azerbaycan, Tacikistan ve Türkmenistan için etkinlik hipotezinin; Kırgızistan için ise telafi hipotezinin geçerli olduğunu ortaya koymuştur.

Anabtar Kelimeler: Küreselleşme, Kamu Harcamaları, Ticari Açıklık, Telafi Hipotezi, Etkinlik Hipotezi

Testing the Validity of the Compensation and Effectiveness Hypotheses in the Turkic Republics

\section{Abstract}

One of the indicators of integration into the global system, which is a reflection of liberalization trends, is the degree of trade openness. The effect of economic and political changes and increasing globalization efforts on public size through the public expenditure channel in the Turkic Republics (Azerbaijan, Kyrgyzstan, Kazakhstan, Turkmenistan, Tajikistan and Uzbekistan), which became independent after 1991, is examined by the efficiency and compensation hypotheses in economic theory. The focus of the study is to test the validity of these hypotheses in these countries. Trade openness as an indicator of globalization and government expenditure as an indicator of public size were used. The analysis covers the period of 1997-2017. Empirical results have shown that the efficiency hypothesis is valid for Azerbaijan, Tajikistan and Turkmenistan, and the compensation hypothesis is valid for Kyrgyzstan.

Key Words: Globalization, Public Expenditure, Trade Openness, Compensation Hypothesis, Efficiency hypothesis

\section{Atıf İçin / Please Cite As:}

Bayraktar, S., Soyyiğit, S. (2021). Türki Cumhuriyetlerde Telafi ve Etkinlik Hipotezi Geçerliliğinin Sınanması. Manas Sosyal Arastormalar Dergisi, 10(3), 1745-1757.

Geliş Tarihi / Received Date: 17.12.2020

Kabul Tarihi / Accepted Date: 14.03.2021

\footnotetext{
${ }^{1}$ Doç. Dr. - Kırlkkale Üniversitesi İ̈BF, sedabayrakdar@hotmail.com

(D) ORCID: 0000-0003-3879-6561

2 Doç. Dr. - Kırklareli Üniversitesi İ̈BF, semanur.soyyigit@klu.edu.tr 


\section{Giriş}

Komünizm sonrası ortaya çıkan devletler Dünya Bankası tasnifine göre Avrupa ve Avrasya olmak üzere ikiye ayrılmaktadır. Bu sınıflandırmada coğrafi konum ön plana çıkmaktadır. Avrupa kategorisinde olan ülkeler Doğu ve Orta Avrupa: Çekya, Macaristan, Polonya, Slovakya; daha başarılı olan eski Balkan ve Yugoslav Cumhuriyetleri: Slovenya, Hirvatistan, Makedonya, Romanya, Bulgaristan ve Baltık Devletleri: Estonya, Litvanya, Letonya'dır. Avrasya kategorisi eski Sovyet Cumhuriyetleri Belarus, Özbekistan, Kırgizistan, Kazakistan, Rusya, Türkmenistan, Azerbaycan, Tacikistan, Ermenistan, Ukrayna, Gürcistan, Moldova'yı içermektedir. Ayrıca Arnavutluk ve Baltıklar da geçiş ekonomilerinde yer alan ülke grubuna dahildir (Orenstein ve Martine, 2005, s. 132). Bu ülkelerde siyasal yapının değişim sancıları beraberinde ekonomik yapıdaki dönüşümü de getirerek korumacılıktan liberalleşmeye dolayısıyla küreselleşmeye uzanan bir eğilimin oluşmasına neden olmuştur. Artan liberalleşme eğilimleri ticarette ve kamusal politikalarda kendini çeşitli şekillerde göstermektedir.

Ticaretin serbestleştirilmesi ve bu konuya ilişkin tartışmalar A. Smith’e kadar uzanmaktadır. 1960 ve 1970’li yıllar, kısıtlayıcı ticaret uygulamaları ve korumacılığın ivme kazandığı yıllardır. GATTT Anlaşmasıyla beraber korumacılığa karşı önyargıları yumuşatılması, serbest ticaret bölgelerinin yaygınlaştırılması, ticaretin serbestleşmesi gibi girişimler başarılı bir şekilde tamamlanmıştır. Son deneyimler ise küreselleşmenin ve serbest ticaretin etkileri üzerine tartışmaların yaşanmasına neden oluştur (Abizadeh, 2005, s. 1881). Küreselleşmenin refah devletini nasıl etkilediği sorusu literatürde sıklıkla tartışılmaktadır. Küreselleşme ve refah devletinin niceliksel bir yansıması olarak kamu büyüklüğünün çeşitli boyutları arasındaki ilişkiler konusunda temel olarak iki görüş bulunmaktadır. Bunlardan birincisi verimlilik hipotezi (efficiency hypothesis), bir diğeri ise telafi hipotezidir (compensation hypothesis).

Bu iki hipotez, küreselleşmenin bir göstergesi olarak kullanılan ekonomik açıklığın ortaya çıkardığı sonuçları, kamu harcamalarını dikkate alarak kamu büyüklüğü üzerinde yol açtığı etkiyi araştırmaktadır. Verimlilik hipotezi uyarınca, ekonomilerde yükselen küreselleşmenin, kamu harcamalarında aşağı yönlü bir bask1 yaratacağına yönelik ampirik çalışmalar olduğu gibi (Cusack, 1997; Rodrik, 1997, 1998; Alvarez, Pascual ve Romero, 2003; Petrou, 2014); telafi hipotezi uyarnnca tam tersini iddia eden, artan faktör hareketliliğinin yarattığı dış riskler nedeniyle sosyal güvenlik için daha yüksek bir talep artışının kamu harcama seviyesini yukarıya çıkaracağını iddia eden çalısmalar da bulunmaktadır (Cameron, 1978; Ruggie, 1982; Katzenstein, 1985; Adam ve Kammas, 2007; Shelton, 2007; Epifani ve Gancia; 2009). Bu literatüre ek olarak kamu büyüklüğü ve küreselleșme arasında herhangi bir ilişkinin olmadığı ya da ilişkinin belirsiz olduğu ampirik çalışmalar da literatürde yer almaktadır (Alesina ve Wacziarg, 1998; Garrett ve Mitchell, 2001; Abizadeh, 2005; Dreher, Sturm ve Ursprung, 2008; Şener, Bayrakdar ve Hacıoğlu; 2015; Kittel ve Winner; 2005; Aydoğuş ve Topçu; 2013).

Bu çalışmanın odak noktası, SSCB'nin dağılması sonrasında bağımsızlıklarına kavuşan Türki Cumhuriyetlerde meydana gelen büyük dönüşümün ardından yaşanan küreselleşmenin kamu büyüklügüne etkilerini incelemektir. Serbest piyasa ekonomisine geçiş süreciyle, kamunun ekonomik büyüklügünde bir değişim ortaya çıkarmaktadır. Bu değişimin kamu büyüklüğünde bir artış $\mathrm{m}$ azalış $\mathrm{m} 1$ yaratacağı sorusu ise ülkelerin kendi dinamiklerine göre cevaplandırılabilir. Ad1 geçen ülke ekonomilerinde serbest piyasa koşullarına uygun kurumların eksikliği, devletin düzenleyici ve denetleyici rolünün beklentileri karşılayamaması akabinde küreselleşme sürecinin ortaya çıkardığı kırılganlıkların kamunun uygulamıs olduğu kurtarma paketleri ve müdahalelerle telafi edilmeye çalışılması; ya da uygulanmaya çalışılan özelleştirmeler ve serbest piyasayı güçlendirmeye yönelik ekonomi politikaları kamu büyüklüğü ve ticari açıklık ilişskisinin hangi yönde ilerlediğinin araştırılmasını gerekli kılmaktadır.

Bu makalede ülke grubu olarak Türki Cumhuriyetler seçilmiştir. Söz konusu ülkeler özelinde yapılan herhangi ampirik bir çalışmaya ulaşılamaması nedeniyle bu çalışmanın literatüre bir katkı sağladığına inanılmaktadır. Bu kapsamda, çalışma şu şekilde düzenlenmiştir: ilk kısımda kamu büyüklüğü ve ticari açıklık arasındaki ilişkinin teorik ve kuramsal temeline yer verilecek, ikinci kısımda konuya ilişkin yapılan ampirik çalışmalardan oluşan geniş bir literatür incelemesi yer alacaktır. Üçüncü kısımda analizde kullanılan değişkenler ve izlenen metodoloji açıklanarak, dördüncü kısımda elde edilen ampirik sonuçlara yer verilecektir. Çalışmanın sonuç kısmında ise elde edilen ampirik bulgular, ülke grubunun özellikleri kapsamında iktisadi olarak tartışılmaktadır. 


\section{Kamu Büyüklüğü ve Küreselleşme Arasındaki İlişkinin Teorik Altyapısı}

Politika yapıcılar küreselleşmenin bir sonucu olarak kamu harcamalarını artırabilmekte ya da azaltabilmektedirler. Kamu harcamalarının artması ya da azalması küreselleşmenin ülkeye sağladığ1 fayda ya da maliyetler sonucunda ortaya çıkmaktadır. Rodrik'e göre küreselleşme, kamunun merkezi işlevlerinden biri olan ve soğuk savaş sonrası devam eden liberalleşmeye yönelik sosyal bütünlüğü ve iç politik desteği korumaya yardımcı olan sosyal sigorta (transferlerin) sağlanmasını son derece zorlaştırmıştır. Esasen, kamu yönetimleri mali güçlerini yerli grupların aşırı piyasa risklerinden, özellikle dışardan kaynaklanan risklerden, korumak için kullanmaktadırlar. Gerçekte ekonomilerin diş ticaret şoklarına maruz kalması ile refah devletinin büyüklüğü arasında çarpıcı bir ilişki bulunmaktadır. Ekonomik entegrasyon kamunun ve azalan sosyal yükümlülüklerin yerini almaktadır. Dolayısıyla refah devleti saldırı altındadır. Sermayenin artan hareketliliği birçok nedenden ötürü sosyal sigorta ihtiyacını azaltmamıştır. Uluslararası entegrasyon sonucu bunlar daha da artmıştır. Küreselleşme ile riskin sosyalleşmesine yönelik baskılar akıllı ve yaratıc1 şekilde yönlendirilmezse, korumacılığın yeniden canlanması olasıdır (Rodrik, 1997, s. 32-33). Rodrik'ten aktaran (Yılmaz Şahin ve Ceylan, 2018, s. 503) telafi hipotezini açıklarken, kamu büyüklüğü ve ülkelerin dişa açıklığ1 arasındaki ilişkide tamamlayıcı rolün altını çizmektedir. Ülkelerin dışa açıklığı sonucu artan risklere karşı kamunun sosyal güvenlik sistemine yapmış olduğu harcamalarla riskleri telafi etmeye çalışması kamu büyüklügünü de artırmaktadır. Hükümetler kamu istihdamı veya sosyal programlarla söz konusu riske maruz kalan kimselerin ihtiyaçlarına cevap vermektedirler. Epifani ve Gancia, dışa açık ekonomilerde kamu büyüklüğünün artmasını özetle iki ana nedene bağlamaktadırlar. Birinci neden, ticari dişa açıklığın vergilemenin iç maliyetini azaltacağ1, bu sebeple kamu büyüklüğünün artacağıdır. İkinci neden, sigorta talebidir; buna göre, ekonominin dışa açılması nedeniyle karşı karşıya kalacağı dış risklerin olumsuz etkilerini en aza indirmek için kamu harcamalarının artırılması talep edilecektir. Bunun sonucu olarak dişa açıklık artıkça kamu harcamaları da artmış olacaktır (Epifani ve Gancia, 2009, s. 630-631). Ülkeler dünya ile ticaret yoluyla bütünleştikçe yani daha dişa açık hale geldikçe küreselleşme tarafindan üretilen risklere de daha açık hale gelmektedirler. Artan risklerin ortaya çıkardığı olumsuz etkilerin bertaraf edilmesinde görev, kamuya ve politika yapıcılara düşmektedir. Artan dış risklerin yarattı̆̆1 zararlar kamu harcamaları ile giderilmeye çalışılmaktadır. (Rodrik, 1998; Gemmell vd.. 2008).

Verimlilik hipotezinin temel iddiası, kamu harcamaları yüzünden ulusal üreticilerin uluslararası mal ve hizmet piyasalarındaki rekabet gücünün azalmasıdır. Kamuya sunulan hizmetler için herhangi bir pazar yoktur bu nedenle pazar kısıtlaması da yoktur. Gelir transfer programları ve sosyal hizmetler işgücü piyasalarını bozmakta ve zamanlar arası yatırım kararlarını saptırmaktadır. Ayrıca, kamu harcamaları genellikle kısa vadede borçlanılarak yapılmakta ve sonuç olarak bu borçlar daha yüksek vergilerle finanse edilmektedir. Gelir ve servet üzerinden alınan vergiler varlık sahiplerinin varlık değerlerini aşındırmakta ve yatırımları olumsuz etkilemektedir. Ek olarak borçlanma reel faiz oranlarının yükselmesine ve yine yatırımların bundan olumsuz etkilenmesine neden olmaktadır. Aynı zamanda, reel döviz kurunda ortaya çıkabilecek bir değer artışı ulusal üreticilerin rekabet güçlerini azaltmaktadır. Bu nedenle, verimlilik hipotezinde kamu büyüklüğü ve ticaret arasındaki ilişkide sıfır toplamlı bir kalite söz konusudur. Ticaretin serbestleştirilmesinin ulaşım ve iletişimde dışsal teknolojik yeniliklerin kaçınılmaz ürünü olarak mı yoksa uluslararası ticaretin faydalarını (ölçek ekonomileri, karşılaştırmalı üstünlükler) elde etmek için kamunun bilinçli seçimi olarak mı gördüğünün önemi yoktur. Her iki durumda da ticaret kamu harcamalarını kısıtlamalıdır. Özetle, verimlilik hipotezi, giderek artan küresel pazar ölçeğinin bir sonucu olarak kamu harcamalarının düşük bir seviyede seyretmesi gerektiğini ileri sürmektedir. Verimlilik hipotezinde, kamu harcamalarının ekonomik maliyetine odaklanması, küreselleşmeye tepki olarak kamu ekonomisini genişletmek için siyasi teşvikler olması ve bunların pazar entegrasyonunun getirdiği kısıtlamalardan daha ağır basma olasılı̆̆ı göz ardı edilmektedir. Küreselleşme ürün ve yatırımın daha verimli tahsisi yoluyla uzun vadede toplumun tüm kesimine fayda sağlayabilir. Ancak küreselleşmenin kısa vadeli siyasi etkilerinin çok farklı olması muhtemeldir. Piyasaların kapsamının genişlemesi eşitsizliği ve ekonomik güvensizliği artıracağından kamu harcamalarına yönelik vatandaşın desteği ortaya çıkacaktır. Heckscker- Ohlin modeline göre, genişleyen ticaret nispeten kıt üretim faktörlerine yönelik talebi azaltırken bol faktörlere olan talebi artırmaktadır. Bu etki gelişmekte olan ülkelerde daha fazla eşitsizliğe yol açmaktadır. Sonuç olarak, ticaretin büyümesinin gelişmiş sanayi demokrasilerinde ekonomik güvensizliği daha fazla artırması olası değildir. Ancak gelişmekte olan ülkelerde oynaklık ve dolayısıyla ekonomik güvensizlik daha yaygın olmaktadır (Gareett, 2001: s. 5-6). Bu sebeple liberalleşme eğilimleri farklı ülke gruplarında farklı sonuçlara yol açacaktır. Aşağıda bu konuda yapılmış geniş bir yazına yer verilmektedir. 


\section{Literatür İncelemesi}

İgili literatürdeki ilk makalelerden biri Cameron (1978)'a aittir. Ticari açılık ile kamu harcamaları arasında pozitif bir eşbütünleşme ilişkisi bulunan çalısmada, kamu kesimi büyüklügünün göstergesi olarak GSYH'de vergi gelirinin payı, ekonomik açıllık ölçütü içinse toplam ihracat ve ithalatın GSYİH içindeki payı kullanılmıştır. Ruggie (1982), kamu büyüklüğ̈ ve dışa açıklık ilişkisinde pozitif bir korelasyon olduğunu, dışa açıklık artıkça kamu büyüklüğünün artırdığını ileri sürmektedir. Katzenstein (1985), nispeten daha küçük olan Avrupa Devletleri için "telafi hipotezinin" geçerli olduğunu göstermektedir. Bu devletler, uluslararası ticaretin sebep olabileceği riskleri ve siyasi patlamaları önlemek için çeşitli sosyal ve ekonomik politikalar geliştirmişlerdir. Cusack (1997) etkinlik hipotezini 16 ülke için, panel veri yöntemiyle analiz etmiştir. Çalışmanın sonucu uyarınca literatürde ilk defa kamu harcamaları ile uluslararası finansal entegrasyon arasında negatif ilişki olduğu sonucuna ulaşmıştır. Rodrik (1998)'e göre açıklık ülkelerin dış şoklara daha fazla maruz kalmasına sebep olmaktadır. Bu nedenle ekonomide stabilizasyon için daha büyük bir kamuya ihtiyaç ortaya çıkmaktadır. Alesina ve Wacziarg (1998), ticari açıklık ve kamu büyüklüğü arasında dolaylı bir ilişki bulunduğunu; küçük ülkelerde kamu büyüklüğünün daha yüksek olduğunu ifade ederek, bunun nedenini küçük ülkelerin ölçek ekonomilerinden faydalanamaması olarak gösterilmişlerdir. Kamu büyüklüğü ve dışa açıklık arasında negatif yönlü bir ilişki buldukları çalışmalarında, analizi değiştirerek ülke büyüklüğünün modelden dışlanması halinde görülen korelasyon ilişkisinin tersine dönerek pozitif olacağını ifade etmektedirler. Garrett ve Mitchell (2001) ekonomik açıllğı ticari açıklık ve finansal açıklık olarak ayırmıştır. Kamu harcamaları içerisinde sosyal güvenlik harcamaları ve ticari açıklık arasında negatif yönlü bir ilişki; kamu harcamaları, doğrudan yabanc1 yatırım ve finansal açılık arasında ise istatistiksel olarak anlamsız bir ilişki ortaya çıkmıştır. Adsera 've Boix (2002) çalışmalarında kamu büyüklüğü ve ticari entegrasyon arasındaki ilişkinin pozitif bir korelasyona sahip olduğu sonucuna ulaşmışlardır. Bretschger ve Hettich (2002), on dört OECD ülkesi içerisinde kamu büyüklüğü ve küreselleşme ilişkisini etkinlik ve telafi hipotezi çerçevesince araştırmışlardır. Çalışmalarında, küreselleşmenin işgücü vergilerini ve sosyal harcamaları artırdığ1 sonucuna ulaşılmıştır. Küreselleşmenin kurumlar vergisi üzerinde ise negatif yönlü bir etkisi bulunmaktadır. Dolayısıyla küreselleşme vergi üzerinde verimlilik etkisini ortaya çıkarırken, sosyal harcamalar üzerinde telafi hipotezini ortaya çıkarmaktadır. Alvarez, et.al.. (2003), dışa açıklık ve kamu harcamaları arasındaki ilişkinin negatif olduğunu ifade ederek, verimlilik hipotezinin geçerli olduğu sonucuna ulaşmışlardır. Abizadeh (2005), ticaretin serbestleştirilmesinin kamunun ekonomideki rolü üzerine etkisini araştırdıkları çalışmalarında küçük ve dışa açık ekonomilerde (Kanada, Singapur, Uruguay) ticaretlerin serbestleşmesinin kamunun büyüklüğü azalttığı sonucuna ulaşmışlardır. Bununla beraber, Kore, Mısır, ABD için bu ilişkinin yönü pozitif olarak bulunmuştur. Yani, söz konusu ülke grubunda ticari serbestleşme artıkça kamu büyüklüğü de artmaktadır. Kittel ve Winner (2005), kamu harcamalarının daha çok ekonominin içerideki durumundan yönlendirildiğine dair kanıtlar bulmuşlardır. Uluslararası ekonomik çevrelerin ve partizan etkilerin kamu harcamalarını etkilemediği yönünde kanıtlar bulunmuştur. Adam ve Kammas (2007), 17 OECD ülkesini inceleyerek, küreselleşmenin etkinlik ve telafi etkilerinin ortak varlığını araştırmışlardır. Regresyon analizi sonucunda daha yüksek ekonomik entegrasyonun ve buna bağlı dış riskin, daha yüksek vergiler gerektiren sosyal güvenlik politikalarına olan gereksinimi artırdığı görülmüştür. Kim (2007), ekonomik açıklık ve oynaklık arasındaki ilişkinin aslında hem teorik hem de ampirik olarak tartışmalı olduğuna dikkat çekerek, oldukça büyük bir veri seti ile 1950-2002 yılları arasında 175 ülke üzerinde araştırma yapmıştır. Yapılan araştırmada ekonomik volatilite ve kamu büyüklügü arasındaki nedensellik ilişkisinin yanlış kurgulandığına yönelik eleştirilerinin ötesinde, analizinin ana temasında ekonomide dışa açılma seviyesinde yükselmenin daha fazla volatiliteye sebep olmayı gerektirmeyeceği yer almaktadır. Ana konunun, ekonomik dalgalanmalara bağlı olarak dış risk miktarı olduğu ifade edilmektedir. Shelton (2007) yüzden fazla ülkeyi kapsayan çalışmasında devlet harcamalarını savunma, eğitim, sağlık ve aynı zamanda merkezi ve yerel yönetim harcamaları olarak sınıflandırmıştır. Ticari açıklı̆̆ın artmasıyla ilişkili harcamaların siyasi ve gelir eşitsizliğini ilgilendiren kısmının sosyal sigorta kapsamını etkilediğine yönelik kanıtlar bulunmaktadır.

Önemli ve detaylı araştırmalardan biri olan Dreher vd. de (2008) yapmış oldukları araştırmada küreselleşmenin kamu harcamalarının kompozisyonunu etkileyip etkilemediğini analiz edebilmek amacıyla iki farklı veri seti ve küreselleşmenin çeşitli ölçüm yöntemi kullanılmıştır. Araştırma sonucunda yapılan analizler uyarınca küreselleşmenin kamu harcamaları kompozisyonunu etkilemediği görülmektedir. Bunun nedenine yönelik potansiyel ilk açıklama verimlilik ve telafi etkilerinin birbirini etkisiz hale getirmesi, ikinci açıklama küreselleşmenin etkilerinin belirsiz olmasıdır. Üçüncü ve son açıklama da küreselleşme üzerine ortaya atılan bu yaygın tartışmaların aslında gerçekte var olmadığıyla alakalıdır. Epifani ve Gancia (2009) kamu büyüklüğü ile ticaret açıklığı arasındaki ilişkiyi incelemişlerdir. Çalışmada, ticari açıklığın artması 
halinde, kamu büyüklüğünün de artığı sonucuna ulaşılmıştır. Bunun sebebi olarak ticaret dişsallığının artması ve sigorta talepleri gösterilmektedir. Avrupa ülkelerini Doğu ve Batı Avrupa ülkeleri olarak refah sistemleri bağlamında ayıran Leibrecht, Klien ve Onaran (2011) çalışmalarında, Batı Avrupa ülkeleri ile ilgili olarak küreselleşmenin sosyal korumaya yönelik kamu harcamalarında bir artışa neden olacağı ifade edilmektedir. Bu bulgu, seçmenlerin küreselleşme çă̆ındaki gelir kayıplarına karşı savunmasızlıklarını önlemeye yönelik talepler olarak değerlendirilebilir. Bu nedenle ortaya çıkan sonuç, telafi hipotezini destekler niteliktedir. Doğu Avrupa ülkelerinde ise tam tersi bir durum ortaya çıkmaktadır. Küreselleşme nedeniyle sosyal koruma harcamalarının payında önemli bir düşüş gözlemlenmektedir. Dolayısıyla, etkinlik hipotezi geçerlidir. Sáenz, Sabaté ve Gadea (2013). İspanya'da zaman serisi yöntemiyle demokratik değişimleri de dikkate alan bir model kullanarak kamu harcamaları ve ekonomik açıklık arasındaki ilişkiyi incelemişlerdir. Çalışmanın sonucunda ilk etapta kamu büyüklüğü ve ekonomik açıklık arasında pozitif yönlü bir ilişki kurulurken modele demokrasi değiş̧keninin kukla değişken olarak eklenmesiyle sonuç tersine dönmektedir. Aydoğuş ve Topçu (2013), Türkiye ekonomisinde kamu büyüklüğü ile ticaret açıklı̆ğ arasında uzun vadede eşbütünleşme ilişsisine rastlamamışlardır. Buna ek olarak, çalışmada kamu büyüklüğünden ticarete tek yönlü bir nedensellik ilişkisi bulunmuştur. Aregbeyen ve Ibrahim (2014), kamu harcamaları ve ticari açıklı ilişkini araştırdıkları çalışmalarında artan ticari açıklı̆̆n yol çatığı risklerin etkilerini hafifletmek için kamu harcamalarının artırılmaya devam edilmesi gerektiğini ifade ederek, telafi hipotezinin Nijerya'da geçerli olduğu sonucuna ulaşmışlardır. Petrou (2014), kamu büyüklüğünün belirleyicilerini incelemiştir. Çalışmada ticari açıklık, ithalat ve ihracatın GSYIHH içindeki payı ile ölçülmektedir. Çalışmanın sonucu olarak, ticaret açıklığının yüksek olduğu ülkelerde, kamu harcaması azalmaktadır, bu sonuç verimlilik hipotezi ile tutarlıdır. Zortuk ve Beşer (2014) yirmi dört geçiş ekonomisi için yapmış oldukları çalışmada demokratik yapısı güçlü olan geçiş ülkelerinin telafi hipotezine uygunluğu kısmen daha fazlayken, Bosna Hersek- Ukrayna, Gürcistan ve Moldova'da telafi hipotezinin geçerli olduğu sonucuna ulaşılmıştır. Bu ülkelerde kamu büyüklüğü ticari açılıktaki değişmelerden bağımsız olarak dış risklerle pozitif ilişkilidir. Şener, Bayrakdar ve Hacıoğlu (2015) Türkiye ekonomisi için yaptıkları analizde hem verimlilik hem de telafi hipotezinin varlığını kanıtlayacak eşbütünleşme ilişkisine ait herhangi bir bulguya ulaşamamışlardır. Taşar (2016) Türkiye ekonomisi için yaptı̆̆ analizde ticari açıklık oranı artıkça kamunun harcamalarını artırdığı sonucuna ulaşmıştır. Dolayısıyla çalışmanın ampirik kanıtları telafi hipotezini kanıtlar niteliktedir. Yay ve Aksoy (2017) otuz iki ülkeyi inceledikleri çalısmalarında küreselleşmenin refah devleti üzerine direkt bir etkisini kanıtlayan herhangi bir sonuca ulaşılamamıştır; fakat ülkelerin refah sistemleri ilişkiyi etkilemektedir. Sosyal demokrat, muhafazakâr ve Akdeniz refah devleti yönetim şekillerine sahip ülkelerde telafi hipotezine yönelik kantlar bulunurken, liberal refah devletlerinde verimlilik etkisi ortaya çıkmaktadır. Yılmaz Şahin ve Ceylan (2018) Türkiye ekonomisinde dışa açıklık ve kamu harcamaları arasında pozitif yönlü bir ilişki bulmuşlardır ve iki değişken arasında çift yönlü bir nedensellik tespit etmişlerdir. Dolayısıyla, Türkiye için telafi hipotezinin geçerliliği ampirik verilerle kanıtlanmıştır. Tütüncü ve Zengin (2018) kamu harcamaları ve dışa açılık arasındaki ilişkiyi MINT ülkeleri için test ettikleri çalışmalarında, söz konusu iki değiş̧en arasında anlamlı bir ilişki olduğu sonucuna ulaşmışlardır. Çalışma sonucunda Meksika ve Türkiye için dışa açılmanın yol açtığı risklerin devlet tarafindan telafi edildiği sonucuna ulaşılmıştır; bir diğer ifadeyle, telafi hipotezi geçerlidir. Endonezya ve Nijerya'da ise dışa açılma sebebiyle kamu harcamalarını negatif etkilendiğini iddia eden etkinlik hipotezi desteklenmektedir.

\section{Veri Seti ve Metodoloji}

Çalısmada, etkinlik ve telafi hipotezinin Türki cumhuriyetler için sınaması yapılmaktadır. Bu bağlamda çalışma Azerbaycan, Kazakistan, Kırgızistan, Tacikistan, Türkmenistan ve Özbekistan’ı kapsamaktadır. Analiz dönemi, veri erişilebilirliğindeki kısıtlardan dolayı 1997-2017 olarak belirlenmiştir. Etkinlik ve telafi hipotezinin sınanması için koentegrasyon analizinin uygulandığı çalışmada, kullanılan değişkenlere ilişkin detaylı bilgi Tablo 1'de verilmektedir.

Tablo 1. Değgiskenler ve Veri Kaynağr

\begin{tabular}{|c|c|c|}
\hline Değişken Adr & Değişkene İlişkin Açıklama & Veri Kaynağ1 \\
\hline LogGov & $\begin{array}{l}\text { Hükümet harcamalarının GSYH'deki } \\
\text { payının logaritması }\end{array}$ & Dünya Bankası \\
\hline LogTrade & $\begin{array}{l}\text { Ticari açıllığın [(İhracat }+ \\
\text { İthalat)/GSYH] logaritması }\end{array}$ & Dünya Bankası \\
\hline
\end{tabular}


Buna göre, çalışma kapsamında iki değişken arasında incelenen ilişki Eşitlik (1)'deki gibi ifade edilebilir:

$$
\text { LogGov }=f(\text { LogTrade })
$$

Eşitlik (1)'in temsil ettiği ilişkide LogTrade değişkeninin LogGov değişkeni üzerinde negatif etkiye sahip olması etkinlik hipotezinin, pozitif etkiye sahip olması ise telafi hipotezinin doğrulanması olarak düşünülmelidir.

Ekonometrik analizde kullanılan değişkenlere ait serilerin durağan olmaları, analiz sonucu elde edilen sonuçların güvenilir olması açısından önemlidir. Durağan olmayan seriler ile analiz gerçekleştirilmesi, sahte regresyon problemine sebep olabilmektedir. Durağanlık analizi bu bakımdan önemlidir. Panel veri ile yapılan analizlerde değişkenlerin durağanlığının tespit edilmesi için kullanılan birim kök testleri, birinci kuşak ve ikinci kuşak birim kök testleri olarak ikiye ayrılmaktadır. Birinci kuşak birim kök testleri, birimler arasında korelasyon yani serilerde yatay-kesit bağımlılık olmadığını varsaymakta iken, ikinci kuşak birim kök testleri birimlere ait seriler arasında korelasyon olduğu varsayımına dayanmaktadır (Yerdelen Tatoğlu, 2013: s.199). Bu sebeple, birim kök testi ile serilerin durağanllğının incelenmesinden önce, birim kök testinin seçilebilmesi için serilerdeki yatay kesit bağımlılık incelenmektedir.

Ekonometri literatüründe yatay-kesit bağımlllŭı test etmek için ilk olarak, Breusch ve Pagan tarafindan Lagrange çarpanı (Lagrange multiplier-LM) testi geliştirilmiştir. T $>\mathrm{N}$ olduğunda kullanılan LM testindeki LM istatistiği $\left(\mathrm{CDLM}_{1}\right)$ Eşitlik (2)'de yer almaktadır (Pesaran, 2004: s.4):

$$
C D L M_{1}=T \sum_{i=1}^{N-1} \sum_{j=i+1}^{N} \hat{\rho}_{i j}^{2}
$$

Eşitlik (2)'teki $\hat{\rho}_{i j}^{2}$, kalıntıların ikili korelasyonunun tahminidir. LM testi N'in görece olarak küçük ve T’nin yeterince büyük olduğu durumlarda geçerli bir testtir. Breusch ve Pagan, seride yatay-kesit bağımlilığ olmadığını ifade eden $\mathrm{H}_{0}$ hipotezi altında, bu test istatistiğinin asimptotik olarak $\chi^{2}$ dağıldığını göstermiştir. Bununla birlikte $N \rightarrow \infty$ olduğunda bu test için uygulanabilirlik ortadan kalktı̆̆ için, Pesaran büyük $\mathrm{N}$ ve $\mathrm{T}$ değerleri için kullanılabilir olan ve $C D L M_{1}$ 'in ölçeklenmiş türü olan $C D L M_{2}$ test istatistiğini geliştirmiştir (Pesaran, 2004: s.5):

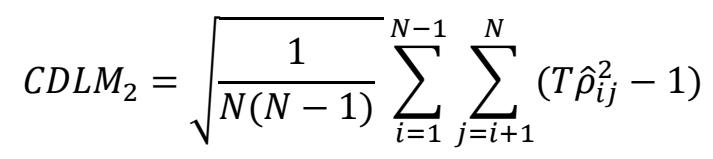

Bu testte de N'in büyük, T’nin küçük değerleri için önemli ölçüde ölçek bozulması meydana gelmektedir. Bu nedenle Pesaran, alternatif bir test istatistiği geliştirmiştir (Pesaran, 2004: s.5). Ancak, bu test de ortalama ikili korelasyonların sıfır olduğu, fakat birimlere ait ikili korelasyonların sıfırdan farklı olduğu durumlarda güçlü sonuç vermemektedir. Daha sonra, Pesaran vd. LM testinin değiştirilmiş bir versiyonu olan ve Eşitlik (4)'te yer alan sapması düzeltilmiş $L M_{a d j}$ test istatistiğini geliştirmişlerdir (Pan vd., 2015: s. 449):

$$
L M_{a d j}=\sqrt{\left(\frac{2 T}{N(N-1)}\right)} \sum_{i=1}^{N-1} \sum_{j=i+1}^{N} \hat{\rho}_{i j} \frac{(T-k) \hat{\rho}_{i j}^{2}-\mu_{T i j}}{\sqrt{v_{T i j}^{2}}}
$$

Yatay kesit bağımlılığın incelenmesinin ardından, serilerin durağanlığının incelenmesi için kullanılacak birim kök testleri belirlenmektedir. Bu çalışmada, her iki değişkende de yatay kesit bağımlılık olduğu tespit edildiğinden, ikinci kuşak birim kök testlerinden MADF (Multivariate ADF) testi kullanılmışır. MADF testi, Taylor ve Sarno tarafindan geliştirilmiş ve panel verinin zaman boyutu yatay kesit boyutundan büyük olduğunda $(T>N)$ kullanılabilen bir testtir (Brooks, 2014: s. 547). Taylor ve Sarno, Nx1 boyutlu stokastik vektörden hareketle Eşitlik (5)'ter yer alan denklemden hareket etmişlerdir (Taylor ve Sarno, 1998: s. 287):

$$
q_{i t}=\mu_{i}+\sum_{j=1}^{k} p_{i j} q_{i t-j}+u_{i t}
$$


Taylor ve Sarno, hata teriminin bağımsız ve normal dağılıma sahip olduğu varsayımından hareketle, birimlere ait her bir otoregresif sürecin kökünün bire yakın ancak birden farklı olduğu durumlarda, tek değişkenli ADF testinin zayıf kalması sebebiyle, Eşitlik (5)'te yer alan denklemi hata terimleri arasındaki eşanlı korelasyonu dikkate alarak tahmin etmişlerdir. Bu testte sıfır hipotezi $\mathrm{N}$ denklem için Eşitlik (6)'daki gibidir (Taylor ve Sarno, 1998: s. 287):

$$
H_{0}: \sum_{j=1}^{k} \rho_{i j}-1=0, \quad \forall i=1, \ldots, N
$$

$\mathrm{Bu}$ test sonucunda Wald test istatistiği elde edilmektedir ve bu test istatistiğine MADF istatistiği de denilmektedir. Eşitlik (5)'deki denklemin tahmininde SUR yöntemi kullanılmaktadır (Taylor ve Sarno, 1998: s. 287). Bu testte sıfır hipotezi altında tüm serilerin durağan olmadığı varsayılmaktadır. Alternatif hipotez altında otoregresif parametrenin birimden birime değişmesine izin vermektedir.

Çalışmada, uygulanan MADF testi sonucunda her iki değişkenin de birinci farkı alındığında durağan hale gelmesi, bu iki değişken arasında koentegrasyon ilişkisi olabileceğini düşündürmektedir. Bu amaçla serilere koentegrasyon sınaması yapılmıştır. Koentegrasyon testleri de koentegrasyon ilişkisini temsil eden denklemin kalıntılarında yatay kesit bağımlılık olup olmamasına göre birinci kuşak ve ikinci kuşak koentegrasyon testleri olmak üzere ikiye ayrllmaktadır. Bu çalışmada inceleme konusu olan ve Eşitlik (1)'de yer alan koentegrasyon denkleminin kalıntılarına yapılan yatay kesit bağımlılık testleri, kalıntılarda yatay kesit bağımlllk olduğunu ortaya koymuş, bu sebeple de ikinci kuşak koentegrasyon testlerinden Westerlund (2006) çoklu yapısal kırılmalı koentegrasyon testi uygulanmıştır.

Westerlund (2006) çoklu yapısal kırılmalı koentegrasyon testi, McCoskey ve Kao'nun LM testine dayalı bir testtir. Test, hem sabitte hem trendde birden fazla yapısal kırllmaya izin vermektedir. Bu testte sıfir hipotez koentegrasyon ilişkisi olduğunu, alternatif hipotez ise koentegrasyon ilişkisinin olmadığını ifade etmektedir (Westerlund, 2006: s. 102). Westerlund aşağıdaki denklem sisteminden hareket etmiştir (Westerlund, 2006: s. 103):

$$
\begin{gathered}
y_{i t}=z_{i t}^{\prime} \gamma_{i j}+x_{i t}^{\prime} \beta_{i}+e_{i t} \\
e_{i t}=r_{i t}+u_{i t} \\
r_{i t}=r_{i t-1}+\phi_{i} u_{i t}
\end{gathered}
$$

Burada $x_{i t}=x_{i t-1}+v_{i t} \mathrm{~K}$ boyutlu bağımsız değişken vektörü ve $z_{i t}$ deterministik bileşen vektörü iken; $\beta_{i}$ ve $\gamma_{i j}$ ise sırayla bunlara karşıllı gelen parametre vektörleridir. $j=1, \ldots, M_{i}+1$ yapısal kırılmaları temsil etmektedir. Westerlund (2006) testinin sıfır ve alternatif hipotezleri aşağıdaki gibidir (Westerlund, 2006: s. 105):

$$
\begin{array}{ll}
H_{0}: \phi_{i}=0 & \forall i \in i=1, \ldots, N \\
H_{1}: \phi_{i} \neq 0 ; & i=1, \ldots, N_{1} \text { için ve } \phi_{i}=0 ; i=N_{1}+1, \ldots, N i c ̧ \text { in }
\end{array}
$$

Westerlund (2006) koentegrasyon testi iki ayrı sonuç vermektedir. Uzun dönem ilişkisini ifade eden denklemin kalıntılarında yatay kesit bağımlılığı olmaması halinde asimptotik olasılık değeri, söz konusu kalıntılarda yatay kesit bağımlilığ olması halinde ise bootstrap olasllık değeri değerlendirilmektedir. Westerlund (2006: s. 127), kalıntılarda yatay kesit bağımlılığı olması halinde bootstrap yaklaşımının dirençli sonuç verdiğini belirtmiştir. Bu test ile ayrıca değişkenler arasındaki uzun dönemli ilişkide gerçekleşen yapısal kırılmalara ilişkin tarihler de elde edilmektedir.

Değişkenler arasında uzun dönemli bir ilişki olduğu tespit edilirse, bu uzun dönemli ilişkiye ilişkin katsayılar tahmin edilebilmektedir. Ancak öncelikle tahmin edilecek katsayıların homojen mi yoksa heterojen mi olduğu belirlenmelidir. Bunun için Pesaran ve Yamagata (2008) tarafindan geliştirilen homojenlik testi kullanılmaktadır. Bu teste ait hipotezler Eşitlik (10)'daki gibidir (Pesaran and Yamagata, 2008: s. 52):

$$
\begin{aligned}
& H_{0}: \beta_{i}=\beta, \quad \forall i \\
& H_{1}: \beta_{i} \neq \beta_{j}
\end{aligned}
$$


Özetle, sıfır hipotez eğim katsayılarının homojen olduğunu, alternatif hipotez ise eğim katsayılarının heterojen olduğunu belirtmektedir (Pesaran ve Yamagata, 2008: s. 52).

Pesaran (2006), yatay-kesit bağımlılı̆̆1 dikkate alan tahminci geliştirmiştir. Ortak ilişkili etkiler (Common-Correlated Effects-CCE) tahmincisi denilen bu tahminci ile ortalama (CCEMG - Mean Group CCE) ve havuzlanmış (CCEP - Pooled CCE) olmak üzere iki farklı tahmin yapılabilmektedir. CCEMG birim eğimlerinin farklı (heterojen) olması durumunda, CCEP ise birim eğim katsayılarının aynı olması durumunda kullanılmaktadır. Panel eşbütünleşme katsayısı CCEMG tahmincisi ile Eşitlik (11)'deki gibi tahmin edilmektedir (Pesaran, 2006: s. 982):

$$
\hat{\beta}_{M G}=N^{-1} \sum_{i=1}^{N} \hat{\beta}_{i}
$$

Bu eşitlikte $\hat{\beta}_{i}$ her bir yatay-kesit birimi için CCE tahminini vermektedir. Panel eşbütünleşme katsayısı $\hat{\beta}$ ise yatay-kesit birimleri için tahmin edilen katsayıların ortalamasıdır.

\section{Ampirik Sonuçlar}

Metodoloji kısmında açıklandığı gibi, değişkenlere birim kök testi uygulanmadan önce, bu değişkenlerde yatay kesit bağımlılık olup olmadığı belirlenmektedir. Çalışmada kullanılan değişkenlere ait yatay kesit bağımlılık testi sonucu Tablo 2'de verilmektedir.

Tablo 2. Değģskenlere Ait Yatay Kesit Bağrmllhk. Testi

\begin{tabular}{cccc}
\hline Değişken & $\boldsymbol{C D L M}_{\boldsymbol{1}}$ & $\boldsymbol{C D L M}_{\boldsymbol{2}}$ & $\boldsymbol{L M}_{\text {adj }}$ \\
\hline \multirow{2}{*}{ LogGov } & $65.252^{*}$ & $8.079^{*}$ & $7.929^{*}$ \\
& $(0.000)$ & $(0.000)$ & $(0.000)$ \\
LogTrade & $78.720^{*}$ & $10.538^{*}$ & $10.388^{*}$ \\
& $(0.000)$ & $(0.000)$ & $(0.000)$ \\
\hline
\end{tabular}

Parantez içindeki değerler olasılık değerleridir. * 0.01 anlam düzeyini ifade etmektedir.

Tablo 2'deki olasılık değerleri incelendiğinde, serilerde yatay kesit bağımlılık bulunmadığını ifade eden sıfır hipotezi reddedilmektedir. Bir değişkende yatay kesit bağımlılık olması, yatay kesit birimlerinden birinde meydana gelecek şokun diğer yatay kesit birimleri de etkileyeceği anlamına gelmektedir. Bu sebeple, bu değişkenlerde durağanlık araştırlııken yatay kesit bağımlılı̆̆ dikkate alan ikinci kuşak birim kök testlerinden yararlanılması gerekmektedir. İkinci kuşak birim kök testlerinden MADF testi sonucu Tablo 3'te verilmektedir.

Tablo 3. Birim Kök Testi

\begin{tabular}{cccc}
\hline Değiskenler & MADF istatistiği & Gecikme & Kritik değer (5\%) \\
\hline LogGov & 33.427 & 2 & 41.7 \\
LogTrade & 20.202 & 1 & 38.897 \\
$\Delta$ LogGov & 206.518 & 1 & 41.7 \\
$\Delta$ LogTrade & 119.846 & 1 & 41.7 \\
\hline
\end{tabular}

Maksimum gecikme uzunluğu 4 olarak seçilmiş olup, uygun gecikme uzunluğu AIC ve BIC kriterlerine göre belirlenmiştir.

Tablo 3 incelendiğinde, düzeyde MADF istatistiğinin kritik değerden küçük olduğu ve sıfir hipotezin kabul edildiği görülmektedir. Değişkenlerin birinci farkı alındığında ise her iki değişken de durağan hale gelmektedir. Bir diğer ifadeyle, her iki değişken de I(1)'dir. Bu durumda, değişkenler arasında uzun dönemli bir ilişki olup olmadığı koentegrasyon analizi ile incelenebilmektedir. Ancak öncelikle Eşitlik (1)'de yer alan modelin kalıntılarına ait yatay kesit bağımlılı̆ı testi sonuçlarına bakmak gerekmektedir.

Tablo 4. Modele Ait Yatay Kesit Bağımlllık Testi

\begin{tabular}{cl}
\hline CDLM $_{1}$ & LM $_{\text {adj }}$ \\
\hline $60.62^{*}$ & $20.63^{*}$ \\
$(0.000)$ & $(0.000)$ \\
\hline
\end{tabular}

Parantez içindeki değerler olasılık değerleridir. * 0.01 anlam düzeyini ifade etmektedir. 
Tablo 4'e göre, modelin kalıntılarında yatay kesit bağımlılık vardır. Dolayısıyla, kalıntılardaki bu yatay kesit bağımlılığı dikkate alan ikinci kuşak koentegrasyon testi uygulanması gerekmektedir.

Tablo 5. Westerlund (2006) Koentegrasyon Testi

\begin{tabular}{ccc}
\hline Kitllma & LM istatistiği & Bootstrap olaslltk değgeri \\
\hline Sabitte & 5.629 & 0.558 \\
Sabitte ve trendde & -7.938 & 0.470 \\
\hline
\end{tabular}

Westerlund (2006) tarafindan geliştirilen çoklu yapısal kırılmalı koentegrasyon testi sonucunun yer aldığı Tablo 5 incelendiğinde, model kalıntılarında yatay kesit bağımlılık olduğunda dikkate alınan bootstrap olasilık değerinin 0.05 'ten büyük olduğu, dolayisıyla koentegrasyonun varlığını temsil eden sıfır hipotezin reddedilemediği görülmektedir. Özetle, iki değişken arasında uzun dönemli bir ilişki mevcuttur. $\mathrm{Bu}$ uzun dönemli ilişkiye ait katsayıların tahmin edilmesinden önce, eğim katsayılarının homojen mi heterojen mi olduğuna karar verilmesi için Pesaran ve Yamagata (2008)'nın geliştirdikleri eğim homojenliği testi uygulanmıştır. Bu teste ait sonuçlar Tablo 6'da yer almaktadır.

Tablo 6. Eğgim Homojenlï̆i Testi

\begin{tabular}{cc}
\hline$\Delta$ & $\tilde{\Delta}$ \\
\hline $2.16^{* *}$ & $2.333^{* *}$ \\
-0.031 & -0.02 \\
\hline
\end{tabular}

Parantez içindeki değerler olasıllık değerleridir. ** 0.05 anlam düzeyini ifade etmektedir.

Tablo 6'da her iki test istatistiğinin de 0.05 anlam düzeyinde istatistiksel olarak anlamlı oldukları görülmektedir. 0.05 ’ten küçük olan olasilık değerlerine dayanarak, eğim katsayılarının homojen olduğunu belirten sıfır hipotezi reddedilir. Dolayısıyla, uzun dönem katsayı tahmini yapılırken, her bir yatay kesit için ayrı sonuç veren bir tahminci kullanılması yerinde olacaktır. Buna göre CCE yöntemi ile elde edilen uzun dönem ilişki katsayı tahmin sonuçları ise Tablo 7'de verilmektedir.

Tablo 7. Užn Dönem Katsayı Tahmini

\begin{tabular}{cccc}
\hline Ülkeler & Katsay1 & Standart hata & Olas1lik değeri \\
\hline Azerbaycan & $-0.2204^{* * *}$ & 0.129 & 0.088 \\
Kazakistan & 0.126 & 0.132 & 0.338 \\
Kirgizistan & $0.157^{* * *}$ & 0.093 & 0.091 \\
Tacikistan & $-0.852^{* *}$ & 0.355 & 0.017 \\
Türkmenistan & $-0.279^{*}$ & 0.096 & 0.004 \\
Özbekistan & -0.054 & 0.112 & 0.627 \\
\hline
\end{tabular}

*, ** ve ${ }^{* * *}$ sırayla $0.01,0.05$ ve 0.10 anlamlllk düzeylerini ifade etmektedir.

Tablo 7'deki sonuçlara göre; Azerbaycan, Tacikistan ve Türkmenistan'da LogTrade değişkeni LogGov değişkeni üzerinde uzun dönemde negatif bir etkiye sahiptir. Bu ülkelerde iki değişken arasında uzun dönemde negatif bir ilişki söz konusudur. Kırgızistan'da ise pozitif bir ilişki söz konusudur. Bir diğer ifadeyle, LogTrade değişkeni LogGov değişkeni üzerinde uzun dönemde pozitif bir etkiye sahiptir. Kazakistan ve Özbekistan için ise iki değişken arasında uzun dönemde istatistiksel olarak anlamlı bir ilişki söz konusu değildir.

\section{Tartışma, Sonuç ve Öneriler}

SSCB'nin dağılmasından sonra bağımsızliklarına kavuşan Azerbaycan, Tacikistan, Türkmenistan, Kırgızistan, Kazakistan ve Özbekistan'in dünya ekonomisine ve serbest piyasa sistemine eklemlenme çabaları halen sürmektedir. Dünyayla entegrasyonun bir kriteri olan küreselleşmenin bu ülkelerde iktisadi sistemin de değişmesi sonucu kamu büyüklüklerinde ne gibi farkllıklara yol açtı̆̆ı, bir anlamda küreselleşmenin ve değişmekte olan kamu sistemi üzerindeki etkilerini anlamak, daha doğru ekonomik ve politik stratejiler belirlemek için önemlidir.

Küreselleşmenin ülkelerin ekonomilerinde net olarak nasıl bir etkiye yol açacağ1 sorusuna cevap vermek oldukça zordur. Çünkü süreç karışık bir ağ gibi birçok başka faktör tarafından da etkilenmektedir. 
Yabancı yatırımcıların ülkeye ilgisinden kurumsal yapıların istikrarına, demokratik hak ve özgürlüklerden yolsuzluklara, ekonomik iş birliklerinden ülkelerin siyasi ve hukuki farkllıklarına ve hatta geleneksel tutumlara kadar uzanan bu yelpazede sebep sonuç ilişkilerinin yönü de çift taraflıdır.

Çalşmaya konu olan ülkelerde serbest piyasaya geçiş süreciyle beraber, ülkelerin yeniden yapılandırılması, makroekonomik istikrarını sağlayabilmesi için sosyal, mali, politik birçok alanda reform çalışmalarını da beraberinde getirdiği gerçeği yadsınamaz. Elbette bütün faktörleri bir arada analiz etmek oldukça güçtür. Dolayısıyla çalışmanın konusu ile sınırlı olarak söz konusu ekonomilerde diğer faktörlerin söz konusu dönemde sabit olduğu varsayımından hareketle ticari açıllk ve kamu büyüklügü ilişkisi ele alınmaktadir.

Çalışmanın sonucunda, Azerbaycan, Tacikistan ve Türkmenistan'da ticari açılılı değişkeninin kamu büyüklüğü değişkeni üzerinde uzun dönemde negatif bir etkiye sahip olduğu tespit edilmiştir. Bu ülkelerde iki değissken arasında uzun dönemde negatif bir iliş̧ki söz konusudur. Kırgızistan'da ise bu ilişski tersine dönerek pozitif bulunmuştur. Bir diğer ifadeyle, ticari açıklık değişkeni kamu büyüklüğü değişkeni üzerinde uzun dönemde pozitif bir etkiye sahiptir. Kazakistan ve Özbekistan için ise iki değişken arasında uzun dönemde istatistiksel olarak anlamlı bir ilişki söz konusu değildir. Ampirik sonuçlar Azerbaycan, Tacikistan ve Türkmenistan için etkinlik hipotezinin; Kırgızistan için ise telafi hipotezinin geçerli olduğunu ortaya koymuştur.

Etkinlik hipotezinin geçerli olduğu anlaşılan Azerbaycan, Tacikistan ve Türkmenistan'da kamunun yerini özel sektörün ikame ettiği söylenebilmektedir. İş kurma imkânlarının daha kolay olduğu, sözleşmelerin zorlayıcı konusundaki prosedürlerin azlığı dikkat çekmektedir ${ }^{3}$. Ayrıca Azerbaycan ve Türkmenistan'ın büyük enerji rezervlerine sahip olmalanı dış ticarette bu ülkeler lehine bir avantaj yaratmaktadır. Tacikistan ise Rusya'nın Orta Asya'ya açılan kapısıdır ve son dönemde özelleştirmeler ve yapısal reformlar konusunda da gelişmeler kaydetmiştir. Bu faktörlerin, söz konusu ülkelerde etkinlik hipotezinin geçerli olmasında etkili olduğu düşünülmektedir.

Telafi hipotezinin geçerli olduğu Kırgızistan'da ise demokrasi konusunda yaşanan tartışmaların varlığının küreselleşmenin avantajı şeklinde ekonomiye geri dönmemesine sebep olduğu düşünülmektedir. Uzun zamandır süren siyasi çalkantılar Ekim sonrası yaşanan parlamento seçimlerinin seçim komisyonu tarafindan iptal edilmesi, ülkede devletin ağırllğının azalamaması sonucunu da beraberinde getirmektedir. Ayrıca dış borç oranlarının fazlalığı, 2005 ve 2010 yıllarında yaşanan darbeler serbest piyasa sistemine geçişle beraber kamunun büyüklüğ̈nün artmasına neden olmuştur.

Kazakistan ve Özbekistan'da ise araştırma konusu olan değişkenler arasındaki ilişkinin anlamsız olması, sürecin yukarıda da etkilediğini ifade ettiğimiz diğer değisskenler tarafindan belirlendiğine işaret ederek başka bir çalışmanın kapılarını aralamaktadır.

\section{Etik Beyan}

"Türki Cumburiyetlerde Telafi ve Etkinlik. Hipotę̧i Geçerliligininin Sinanması" başlıkl çalışmanın yazım sürecinde bilimsel kurallara, etik ve alıntı kurallarına uyulmuş; toplanan veriler üzerinde herhangi bir tahrifat yapılmamış ve bu çalısma herhangi başka bir akademik yayın ortamına değerlendirme için gönderilmemiştir. $\mathrm{Bu}$ araştırmada hazır veri seti kullanıldığı için etik kurul kararı zorunluluğu taşımamaktadır.

\section{Kaynakça}

Abizadeh, S. (2005). An analysis of government expenditure and trade liberalization. Applied Economics, 37, 18811884.

Adam, A. ve Kammas, P. (2007) Tax policies in a globalized world: is it politics after all?. Public Choice, 133(3), 32141.

Adsera , A.ve Boix, C. (2002). Trade, democracy, and the size of the public sector: the political underpinnings of openness. International Organization, 56, 229-262.

Alesina, A., Wacziarg, R. (1998). Openness, country size and government. Journal of Public Economics, 69 (3), 305-321.

Alvarez, S., Pascual, M. ve Romero, D. (2003). Protección social, globalizacióny crecimiento económico,. Hacienda Pública española, Monografía, 63-77.

Aregbeyen, O., ve Ibrahim, T. M. (2014). Trade openness-government size nexus: compensation hypothesis considered for Nigeria. Journal of Reviens on Global Economics, 3, 364-372.

\footnotetext{
${ }^{3}$ World Bank Group, Doing Business Report, 2020 ülke raporlarında detaylı bilgi bulunabilir.
} 
Aydogus, İ. ve Topcu, M. (2013). An investigation of co-integration and causality between trade openness and government size in Turkey. International Journal of Economics and Financial Issues, 3(2), 319-323.

Bretschger, L. ve Hettich, F. (2002). Globalisation, capital mobility and tax competition: theory and evidence for OECD countries. European Journal of Political Economy, 18(4), 695-716.

Brooks, C. (2014). Introductory econometrics for finance (3.bask1). United Kingdom: Cambridge University Press.

Cameron, D. R. (1978). The expansion of the public economy: a comparative study. American Political Science Review, 72, 1243-1261.

Cusack, T., (1997). Partisan politics and public finance: changes in public spending in the İndustrialized democracies 1955-1989. Public Choice, 91(3-4), 375-395.

Dreher, A., Sturm, J., ve Ursprung, H.W. (2008). The impact of globalization on the composition of government expenditures: evidence from panel data. Public Choice, 134, 263-292.

Epifani, P. ve Gancia, G. (2009). Openness, government size and the terms of trade, Review of Economic Studies, 76(2), 629-668.

Garrett, G. ve Mitchell, D. (2001). Globalization, government spending and taxation in the OECD. European Journal of Political Research, 39(2), 145-177.

Katzenstein, P. (1985). Small states in world markets. Ithaca: Cornell University Press.

Kim, S. Y. (2007). Openness, external risk, and volatility: Implications for the compensation hypothesis. International Organization, 61, 181.

Kittel, B. ve Winner, H. (2005). How reliable is pooled analysis in political economy? The Globalization-Welfare State Nexus Revisited. European Journal of Political Research, 44, 269-293.

Leibrecht, M., Klien, M. ve Onaran, O. (2011). Globalization, welfare regimes and social protection expenditures in Western and Eastern European countries. Public Choice, 148, 569-594.

Orenstein, M. ve Haas, M. R. (2005). Globalization and the future of welfare states in post-communist East-Central European countries. In Globalization and the Future of the Welfare State, Edited by: Glatzer, M. ve Rueschemeyer, D., (ss. 130-152). Pittsburg, PA: University of Pittsburgh Press.

Pan, C., Chang, T. ve Wolde-Rufael, Y. (2015). Military spending and economic growth in the Middle East countries: Bootstrap Panel Causality Test. Defence and Peace Economics 26(24), 443-456.

Pesaran, M. H. (2004). General diagnostic tests for cross section dependence in panels, CWPE,

0435.

Pesaran, M. H., (2006). Estimation and inference in large heterogeneous panels with a multifactor error structure. Econometrica 74 (4), 967-1012.

Pesaran, M.H. ve Yamagata, T. (2008). Testing slope homogeneity in large panels. Journal of Econometrics, 142(1), 5093.

Petrou K. (2014). Government size and trade openness using Bayesian model average. http://www.ucy.ac.cy/econ/documents/seminarpapers/2014/Article_1_Draft_2.pdf

Rodrik, D. (1997). Has globalization gone too far?. California Management Review, 39(3),29-53.

Rodrik, D. (1998). Why do more open economies have bigger governments?. The Journal of Political Economy, 106(5), 997-1032.

Ruggie, J.G. (1982). International regimes, transactions, and change: embedded liberalism in the postwar economic order, International Organization, 36, 379-415.

Sáenz, E., Sabaté, M., ve Gadea, M. D. (2013). Trade openness and public expenditure. the Spanish case, 1960 2000. Public Choice, 154(3-4), 173-195.

Sener, S., Bayrakdar, S., ve Hacioglu, V. (2015). The analysis for the validity of compensation and efficiency hypotheses in Turkey between 1975 and 2013. World Conference on Technology, Innovation and Entrepreneurship. İstanbul, Procedia - Social and Behavioral Sciences.

Shelton, C. A. (2007). The size and composition of government expenditure. Journal of Public Economics, 91, 22302260.

Taşar, İ . (2016). Türkiye'de etkinlik ve telafi edici etki hipotezlerinin geçerliliğinin test edilmesi. Kabramanmaraş Sütçü İmam Üniversitesi İktisadi ve İdari Bilimler Fakültesi Dergisi, 6(2), 15-22.

Taylor, M. P. ve Sarno, L. (1998). The Behavior of Real Exchange Rates During the Post-Bretton Woods Period. Journal of International Economics, 46, 281-312.

Tütüncü, A. ve Zengin, H . (2019). Telafi ve etkinlik hipotezlerinin MINT ülkeleri için geçerliliğinin incelenmesi. Anadolu Üniversitesi Sosyal Bilimler Dergisi, 19(1), 81-94 . DOI: 10.18037/ausbd.550249

Westerlund, J. (2006). Testing for panel cointegration with multiple structural breaks. Oxford Bulletin of Economics and Statistics, 68(1), 101-132.

Yay, G.G.,ve Aksoy,P. (2018). Globalisation and the welfare state. Quality and Quantity, 52(2), 1015-1040.

Yerdelen Tatoğlu, F. (2013). İleri panel veri analizi Stata uygulamalı (2. Baskı), İstanbul: Beta.

Yılmaz Şahin, B. ve Ceylan, S . (2018). Kamu büyüklüğü dışa açıklık ilişkisinin analizi: Türkiye örneği. Yönetim Ve Ekonomi: Celal Bayar Üniversitesi İktisadi Ve İdari Bilimler Fakültesi Dergisi, 25(2), 501-511. 
Ek 1. Uzun Dönem Ilişkideki Yapısal Kurlma Taribleri

\begin{tabular}{ccccc}
\hline \multirow{2}{*}{ Ülkeler } & \multicolumn{2}{c}{ Sabitte kıtılma } & \multicolumn{2}{c}{ Sabitte ve trendde kitılma } \\
& Kitılma sayıs & Kitılma tarihi & Kitılma sayıs & Kitılma tarihi \\
\hline Azerbaycan & 2 & 2005,2013 & 1 & 2005 \\
Kazakistan & 1 & 2004 & 0 & - \\
Kirgizistan & 1 & 2002 & 2 & 2000,2011 \\
Tacikistan & 0 & - & 2 & 2000,2005 \\
Türkmenistan & 2 & 2000,2006 & 1 & 2007 \\
Özbekistan & 2 & 1998,2003 & 1 & 2009 \\
\hline
\end{tabular}

\section{EXTENDED ABSTRACT}

According to the World Bank classification, the emerging states after communism are divided into Europe and Eurasia. In this classification, geographical location comes to the fore. Eastern and Central Europe in the category European countries: Czechia, Hungary, Poland, Slovakia; the more successful Balkan and former Yugoslav republics: Slovenia, Croatia, Macedonia, Romania, Bulgaria and the Baltic states: Estonia, Lithuania, Latvia. The Eurasian category includes the former Soviet republics Belarus, Uzbekistan, Kyrgyzstan, Kazakhstan, Russia, Turkmenistan, Azerbaijan, Tajikistan, Armenia, Ukraine, Georgia, Moldova. Albania and the Baltics are also included in the group of countries involved in transition economies (Orenstein, \& Martine, 2005, p. 132)

Trade liberalization and discussions on this issue date back to A. Smith. The 1960s and 1970s were the years when restrictive trade practices and protectionism gained momentum. Along with the GATT, initiatives such as softening prejudices against protectionism, expanding free trade zones, and liberalizing trade have been successfully completed. Recent experiences have led to discussions on the effects of globalization and free trade (Abizadeh, 2005, p. 1881). The question of how globalization affects the welfare state is often discussed in the literature. There are basically two views on the relationship between various dimensions of public size as a quantitative reflection of globalization and the welfare state. The first is the efficiency hypothesis, and the other is the compensation hypothesis.

These two hypotheses explore the consequences of economic openness, which is used as an indicator of globalization, and the impact it has on public size, taking into account public spending. According to the efficiency hypothesis, empirical studies have shown that rising globalization in economies will create downward pressure on public spending (Cusack, 1997; Rodrik 1997; 1998; Alvarez, Pascual, \& Romero, 2003; Petrou, 2014); according to the compensation hypothesis, claiming the opposite, increased factor mobility, due to external the risks of higher public spending and the increase in demand for social security there are studies that claim that it will level up (Cameron, 1978; Ruggie, 1982; Katzenstein, 1985; and if Man, 2007; Shelton, 2007; Gancia, \& Epiphany, 2009). In addition to this literature, empirical studies in which there is no relationship between public size and globalization, or the relationship is unclear, are also included in the literature (Alesina, \& Wacziarg, 1998; Garrett, \& Mitchell, 2001; Abizadeh, 2005; Dreher, Sturm, \& Ursprung, 2008; Şener, Bayrakdar, \& Hacioğlu; 2015; Kittel, \& Winner; 2005; Aydoğuş, \& Topçu; 2013;)

Policymakers are able to increase or reduce public spending as a result of globalization. An increase or decrease in public spending is a result of the benefits or costs that globalization brings to the country. According to Rodrik, globalization has made it extremely difficult to provide social insurance (transfers), which is one of the central functions of the public and helps maintain social integrity and domestic political support for post-Cold War liberalization. Essentially, public administrations use their financial power to protect domestic groups from excessive market risks, especially external risks. In reality, there is a striking relationship between the impact of economies on foreign trade shocks and the size of the welfare state. Economic integration replaces public and declining social obligations. So the welfare state is under attack. The increasing mobility of capital has not reduced the need for social insurance for many reasons. As a result of international integration, these have increased further. A resurgence of protectionism is likely if the pressures to socialize risk with globalization are not intelligently and creatively directed (Rodrik, 1997, p. 32-33)

The focus of this study is to examine the effects of globalization on public size following the great transformation that took place in the Turkic Republics that gained their independence after the dissolution of the USSR. In this article, Turkic republics were selected as a group of countries. It is believed that this 
study contributes to the literature, since no empirical study conducted in particular in the countries in question can be reached.

The efforts of Azerbaijan, Tajikistan, Turkmenistan, Kyrgyzstan, Kazakhstan and Uzbekistan, which gained their independence after the dissolution of the USSR, to join the world economy and free market system are still continuing. It is important to understand how globalization, which is a criterion of integration with the world, causes differences in public sizes as a result of the change in the economic system in these countries, in a sense, the effects of globalization and the changing public system, to determine more correct economic and political strategies.

It cannot be denied that, along with the transition to the free market in the countries subject to the study, the restructuring of the countries has brought along reform efforts in many social, financial and political fields in order to ensure macroeconomic stability. Of course, it is very difficult to analyze all factors together. Therefore, limited to the subject of the study, the relationship between commercial openness and public size is discussed based on the assumption that other factors in the said economies are constant in the said period.

As a result of the study, it was found that the variable of trade openness in Azerbaijan, Tajikistan and Turkmenistan has a negative effect on the variable of public size in the long-run. In these countries, there is a long-term negative relationship between the two variables. In Kyrgyzstan, this relationship was reversed and found positive. In other words, the trade openness variable has a long-term positive effect on the public size variable. For Kazakhstan and Uzbekistan, there is no statistically significant relationship between the two variables in the long-term. Empirical results have shown that the efficiency hypothesis is valid for Azerbaijan, Tajikistan and Turkmenistan, and the compensation hypothesis is valid for Kyrgyzstan. 